\title{
Helmut Kallmann (1922-2012): A MemoiR
}

\author{
BY MARIA CALDERISI
}

Anyone can read the brief biographical notes on Helmut Kallmann in the Encyclopedia of Music in Canada and in other published sources, and be amazed by the length and breadth of his writings as listed in Musical Canada: Words and Music Honouring Helmut Kallmann, the festschrift edited by John Beckwith and Frederick A. Hall and published by the University of Toronto Press in 1988. But I like to think that it is in the hearts and memories of those who came to know this gentle, modest man by working with him and sharing with him his interest and passion for keeping the record, for collecting and preserving Canada's musical heritage, that Helmut Kallmann's spirit lives on.

Elsewhere in this issue you have an overview of his activities and achievements, along with several testimonials and personal stories. So I shall limit myself to my own experiences shared with him or directly resulting from his encouragement and support.

First of all, I would not have become a music librarian had it not been for Dr. Kallmann, as he was most respectfully called by most of his directors and co-workers at the National Library of Canada. Near the end of my belated music studies at McGill in1972, my favourite professor-after whom McGill's Marvin Duchow Music Library is now named-had dropped the idea of librarianship in my ear. Various enquiries led me to Ottawa to ask Helmut what he thought about the future of music librarianship in Canada. Based on his prognosis I enrolled in a specialized Master's programme at the University of Michigan, and, by the time I graduated in 1973, Helmut had convinced the National Library that he needed a reference librarian to attend to the increasing demands upon the Music Division, then only three years old. The rest, as they say, is history.

Of course I knew about his reputation in the field of music in Canada and was familiar with his publications, but I was not prepared for the extent of his research finding-aids which had made their way into the card catalogue drawers: flimsy paper slips with references to Canadian music publishers, sometimes quite skeletal, others with a full range of dates and addresses as found in a city directory; periodical indexes; biographical notes; picture indexes; and so on, not to mention the banks of filing cabinets with clippings and brochures and others with illustrations and photos, all arranged by individuals, groups or subjects, all with cross-references galore. Feeding these finding-aids and files was a large part of my responsibilities, besides the usual library activities such as reference services and developing the printed collectionwhich itself extended well beyond the usual to concert programmes and pamphlets. Gradually I was drawn into the "quicksand" of fascination and dedication, along with this most unconventional of bosses, who then granted me study leave to return to McGill for a Master's degree in Musicology. My thesis subject was Helmut's suggestion-music publishing in pre-Confederation Canada. 
And along the way, also gradually, we became friends as a result of working so closely together. I learned about his tragic past, his early removal from a safe and loving home in Berlin only to find himself declared an "enemy alien" and thrust into communal living in internment camps in England and Canada, and the subsequent loss of his entire family. I say gradually because Helmut did not reveal his life story in one telling, nor did he dramatize his tragedy. Rather, he liked to talk about his parents, especially his lawyer father who was a music lover and Helmut's first music teacher. He learned the entire Köchel catalogue at an early age, matching numbers to compositions and keys, and when he was ten or so, he organized his father's miniature score collection, by composer and opus number of course! The only time I heard a catch in his throat was when he spoke of his younger sister, Eva. He was even able to talk about the positive aspects of his internment, and the musical activities of his fellow "prisoners" who helped with his interrupted studies and put him in charge of the library! He was always positive, bore no grudges towards his old homeland, or to his new one, and his life's work is ample evidence of that.

I had already joined CAML_of which he was co-founder—as I had MLA, but Helmut encouraged me to get more involved which I did, becoming a board member of both associations and eventually president of CAML. With the International Association of Music Libraries (IAML) conference in Montreal in 1975 I began my activities in that association, again with Helmut's blessing and support. He believed strongly in the benefits of national and international networks, and especially in the exchange of information and collaboration on special projects. He was the first Canadian to correspond with IAML by contributing Canadian locations of pre-1800 publications to RISM (Répertoire international des sources musicales) soon after its inception in the early 1950s. As his duties at the Library became more demanding, and with the beginnings of planning for the Encyclopedia, he passed the torch, so to speak, to those of us who had been inspired by his ideology and dedication. I took on various positions in IAML, served 12 years on the board, including three as president, and remained actively interested even beyond my retirement in 1995. Helmut was pleased about that. Although he attended few conferences after the 1970s, he was always eager to hear reports on the people he knew and the activities of both the Canadian and the international organizations.

The fourteen years I spent working for and with Helmut at the National Library were rich and productive indeed and I remain ever grateful. But we had some lighter moments too. He would whistle a theme and ask us to guess its origin; as like as not it would turn out to be the second violin part from a Haydn string quartet! Music was such an integral part of his makeup that he could hear the old familiar repertoire in his head at any time he chose and hum along on some inner voice. His greatest joy, beyond his family, was playing his piano. He also loved being in nature; he photographed the trees in front of his house every season, marking the changes from year to year. He was happy to share any new family photos, or letters from old, old friends, ex-internees or schoolmates, or from the City of Berlin, grateful for his corrections regarding its tramway system (!) and eager to make whatever belated reparations it could. We talked about politics and travel, language and history, and, of course, music. So many little and great things that 
make up a person! We remained close friends until his death in February and I shall remember him always with deep affection.

Maria Calderis was Head of the Printed Collection and Reference Services (Music Division) at the National Library of Canada from 1973 to 1995. She was President of CAML (1976-1978) and of IAML (1986-1989), having also served on various committees and commissions within both organizations. She was also a delegate to IFLA on behalf of IAML and the Music Library Association (MLA). She is author of Music Publishing in the Canadas 1800-1867 / L'édition musicale au Canada 1800-1867 (Ottawa: National Library of Canada / Bibliothèque nationale du Canada, 1981) and of several articles in the Encyclopedia of Music in Canada. She was also a contributor to History of the Book in Canada / Histoire du livre et de l'imprimé (Bibliographical Society of Canada, 2004-2007) and was guest editor of Fontes Artis Musicae, 48/2 (2001), devoted to the 50th anniversary of IAML. She is married to Nikolas Bryce, former librarian of the National Arts Centre Orchestra. 